\title{
CONTROL SYSTEM OF COKING PLANT
}

The control of coking plant has been analyzed and investigated with the aim of proposing optimum control system. This optimum control system consists of optimization and stabilization levels. New ways of optimization and stabilization have been proposed by using the simulation model. The first optimization level represents the kernel of the optimum control of the coke battery. Exact solution is very difficult and is based upon using a complex simulation model of coking and flow of gas media from mixing station all the way to suction of combustion products into the chimney on the basis of optimization principle with the model. Its result is the determination of optimum performance of each coking battery block in such a way as to produce the required amount of coke within given time interval. This optimization level, because of its extent and difficulty, is at the stage of development and testing. The second optimization level solves in a simple way the optimum stabilization of heating capacity of mixture gas. Optimum heating capacity is solved with a method of linear programming. This optimization level was implemented and has brought positive results.

Key words: the coking plant, the optimum control system, minimization of energy cost, linear programming, stabilization of calorific value

Sistem upravljanja koksarom. Izvršena su ispitivanja i analiziranja upravljanja koksarom s ciljem da se predloži optimalan sistem upravljanja. Optimalan sistem upravljanja se sastoji od nekoliko nivoa optimalizacije i stabilizacije. Korištenjem simulacije modela predloženi su novi načini takve optimalizacije i stabilizacije. Prvi nivo optimalizacije predstavlja suštinu optimalnog upravljanja baterijom koksa. Egzaktno rješenje je vrlo teško a zasniva se na uporabi kompleksne simulacije modela koksiranja i protoka plinskog medija od stanice za miješanje pa sve do mjesta usisavanja produkata sagorijevanja u dimnjak na osnovi principa optimalizacije modelom. Rezultat toga je određivanje optimalne performanse svakog bloka baterije koksa na takav način da se proizvede tražena količina koksa unutar nekog zadanog vremena. Takav nivo optimalizacije je zbog svoje opsežnosti i težine još uvijek na stupnju razvoja $i$ ispitivanja. Drugi stupanj optimalizacije rješava na jednostavan način optimalnu stabilizaciju zagrijavanja kapacitete smjese plinova. Optimalni kapacitet zagrijavanja se rješava metodom linearnog programiranja. Taj nivo optimalizacije se primijenio i donio je pozitivne rezultate.

Ključne riječi: koksiranje, optimalni sistem kontrole, minimalizacija troškova energije, linearno programiranje, stabilizacija ogrjevne vrijednosti

\section{INTRODUCTION}

The reduction of cost in the process of iron manufacture is of permanent interest in steel-making industry. An important part of the overall cost in the process of iron manufacture is the cost of production of metallurgical coke. This problem is solved by finding a new technologies of iron production (COREX) or optimization of current ways of iron production. Therefore we have adopted the method

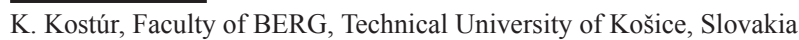

of optimizing inputs to blast furnace. Our aim has been to minimize the cost of coke production.

\section{CHARACTERISTIC OF THE COKING PLANT}

The coking plant usually consists of several blocks (A, $\mathrm{B}, \mathrm{C})$ - see Figure 1., and it is mixed gas-heated. The mixing station mixes the blast-furnace gas and coke-oven gas. Then the mixed gas is distributed to blocks on coke and machinery side. Combustion of mixed gas is realized in 31 combustion chambers from the coke and machinery side. The volume flow of mixed gas depends on the output of the block 


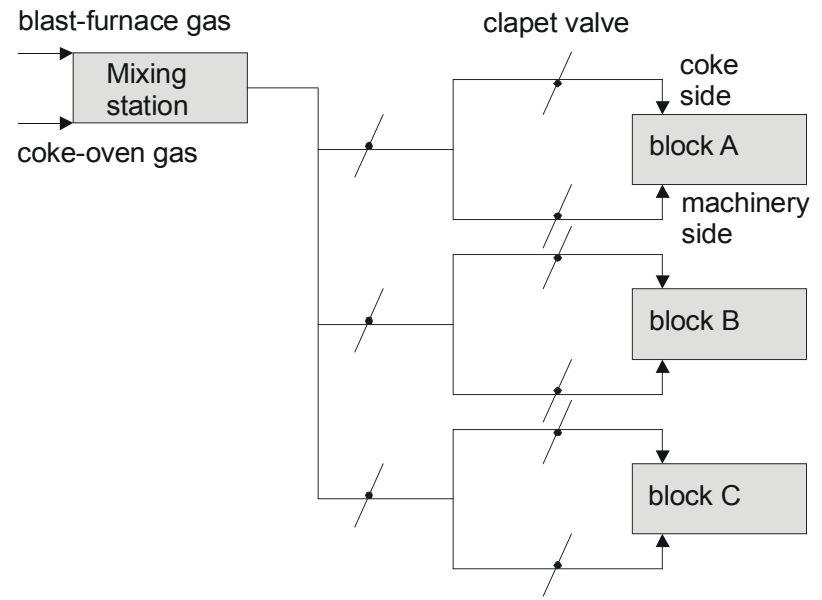

Figure 1. The system of heating in coke plant

Slika 1. Sistem zagrijavanja u koksari

and is regulated by a system of flap valves. At present time the ratio of mixed gases is constant. The combustion of gas fuel in combustion chambers is the source of heat, which by conductivity proceeds to the coal in coke chambers. Combustion chambers are parallel with the coke chambers. The draft of combustion products from combustion chambers to the chimney is opposite to the gas flow from each side of each block and they are connected to the chimney.

\section{FORMULATION OF PROBLEMS}

We started to develop our control system of coking plant for the following reasons:

1. In the past the steel production program was stabilized and the control of coking plant was easy. In the conditions of producer's market and buyer's market the iron and steel production program has rapidly changed. This fact influences the output of coking plant. The heating inertia of plant is large and therefore it is necessary to change the volume flow of mixed gas early.

2. The calorific value of blast-furnace gas is not constant. We made an analysis of the calorific value during August 1999. The results of analysis are shown on Figure 2.. We can see that the calorific value had a fluctuation about $20 \%$ in this month.

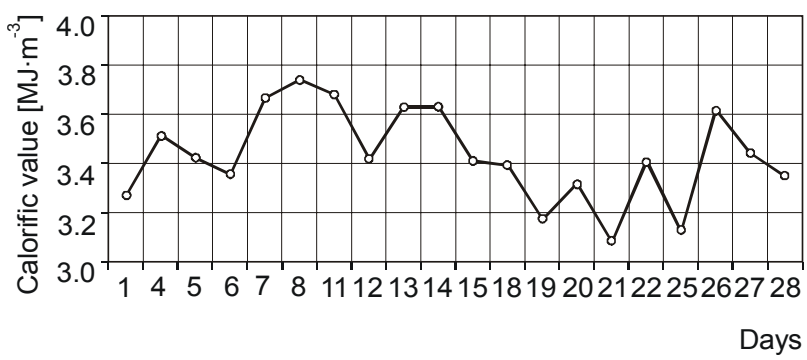

Figure 2. The calorific value of blast furnance gas during one month

Slika 2. Ogrijevna vrijednost visokopećnog plina tijekom jednog mjeseca
From this standpoint we can formulate following requirements on controling.

1. The control system should be flexible. It should have a modular structure consisting of several levels.

2. The aim is optimal control. The objective function will be minimization of energy consumption.

3. The control system has to provide stabilization of the calorific value of mixed gas.

\section{STRUCTURE \\ AND FUNCTIONS OF THE CONTROL SYSTEM}

Because the coking plant is a very complicated system with big material and energy inputs, a two-level structure of control was chosen. Then the optimal control system consists of stabilization and optimization levels - see Figure 3 ..

The task of the optimization level is to compute:

- optimum production program of each block;

- optimum composition of mixed gas.

The optimization of the production program is given by solving the following task.

To minimize the objective function

$F=y_{A}+y_{B}+y_{C}$

with the conditions

$G=x_{A} t_{A}+y_{A} t_{B}+y_{C} t_{C}$

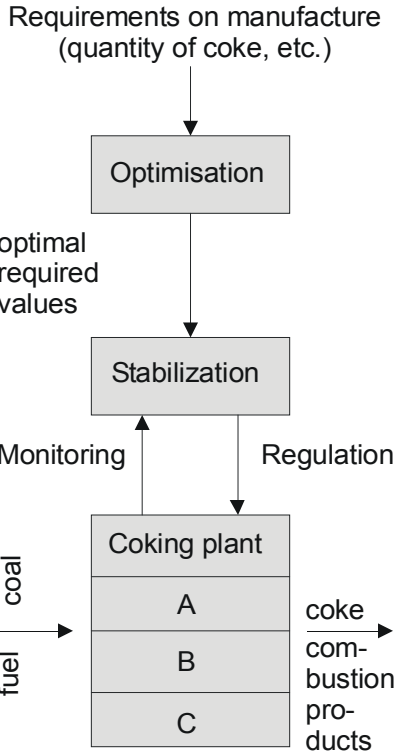

Figure 3. Structure of optimal control system

Slika3. Struktura optimalnog sustava upravljanja

$y_{A} x_{A}+y_{B} x_{B}+y_{C} x_{C} \leq Q^{\max }$

where

$x_{i}$ is the capacity of the $\mathrm{i}$-th block $[\mathrm{kg} / \mathrm{s}]$,

$y_{i}$ is the specific consumption of energy in the $\mathrm{i}$-th block $[\mathrm{J} / \mathrm{kg}]$

$y_{i}=a_{0 i}+a_{1 i} x_{i}+a_{2 i} x_{i}^{2}$,

$t_{i}$ is the time of constant capacity of $\mathrm{i}$-th block [s],

$\mathrm{G}$ is the total required quantity of produced coke $[\mathrm{kg}]$,

$Q^{\max }$ is the maximum (restriction) heating input of coking plant [W].

The solution of this optimization task was described in [1]. The optimum production program is given by vector $x$ solving (1), (2), and (3). 
The optimum composition of the mixed gas is determined by help principle optimization system with the model.

The existence of the simulation model allows direct optimization, the so-called optimization system with the model. This procedure can be described as universal and flexible. It has all the advantages which the classic optimization procedures do not have because they are closed and applicable in simple, often highly idealized processes. Its principle is shown in Figure 4 ..

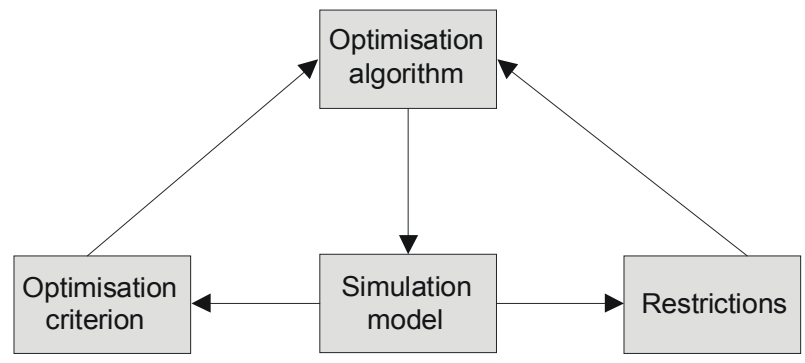

Figure 4. Optimisation system with the model

Slika 4. Sistem optimalizacije pomoću modela

The optimization algorithm may be based on heuristic principles or on a suitable optimization method. Its aim is to control the course of simulation in such a manner as to ensure that the purpose function reaches the extreme value and the system of restrictions is fulfilled. The course of simulation is controlled by changing the input parameters of the model. An algorithm, based on heuristic principles, was used in this application.

The simulation of dynamical model is developed on the basis of a mathematical description of the main thermal processes taking place in every thermal system [2-3]. It includes solving the following processes:

- the combustion of fuel;

- the heat exchange in the furnace space and with the environment (radiation, convection, conduction);

- the flowing of gaseous media;

- the movement of the charge through the coke chamber.

The objective function was used in this form.

To minimize

$$
F=p_{b} \int_{0}^{T} \dot{V}_{b} d \tau+p_{c} \int_{0}^{T} \dot{V}_{c} d \tau
$$

for the following conditions and restrictions

$$
\begin{aligned}
& H \cdot\left(\dot{V}_{b}+\dot{V}_{c}\right)=y_{A} x_{A}+y_{B} x_{B}+y_{C} x_{C} \\
& p_{m}-\sum_{j} p_{j} \leq p_{c h}
\end{aligned}
$$

where $p_{b}, p_{c}$ is the price of one $\mathrm{m}^{3}$ of blast - furnace gas, cokeoven gas [money unit],

$\dot{V}_{b}, \dot{V}_{c}$ is the volume flow of fuel $\left[\mathrm{m}^{3} / \mathrm{s}\right]$,

$H$ is the calorific value of mixed gas $\left[\mathrm{J} / \mathrm{m}^{3}\right]$,

$p_{m}$ is the pressure of mixed gas after mixing station [Pa],

$p_{j}$ is the pressured loss of gaseous media in $\mathrm{j}$-th element of coking plant $[\mathrm{Pa}]$,

$p_{c h}$ is the draft of chimney $[\mathrm{Pa}]$.

The task of the stabilization level is to regulate input variables so as to keep the optimum value from optimization level. The stabilization level provides the following functions:

- stabilization of heating input;

- stabilization of calorific value;

- stabilization of draft combustion products;

- stabilization of combustion ratio (air-fuel).

These functions have to be realized for each block and each side of block. Here we describe only one very important circuit for stabilization of calorific value.

The feedback stabilization system was not suitable in the past, because the mixing of gases in mixing station was imperfect. From this standpoint the measurements of calorific value of mixed gas were unreliable. The feedback system then worked unreliably as well. Therefore a new forward control system was chosen -see Figure 3 .. The forward control system measures the calorific capacity and volume flow of both gases. The optimization level brings the information about optimal calorific value $\left(H^{0}\right)$.

The optimization level computes the optimum heat capacity dependent on the efficiency of the coke battery.

Mathematically, the problem was formulated as follows. Minimize

$F=c_{b} Q_{b}+c_{c} Q_{c}$

with constraints

$Q_{b}+Q_{c}=b$

$0 \leq Q_{b} \leq Q_{b}^{\max }$

$0 \leq Q_{c} \leq Q_{c}^{\max }$

where

$c_{b}, c_{c}$ are unit prices of blast furnace and coke gas energy [monetary unit /J],

$Q_{b}, Q_{c}$ are heat flows brought by the blast furnace and coke gas into coke battery,

$b$ is required heat flow through the coke battery [W].

The required heat flow depends on the efficiency of the coke battery and in the case where the constraints (3) are satisfied it can be determined according to relation (11) 


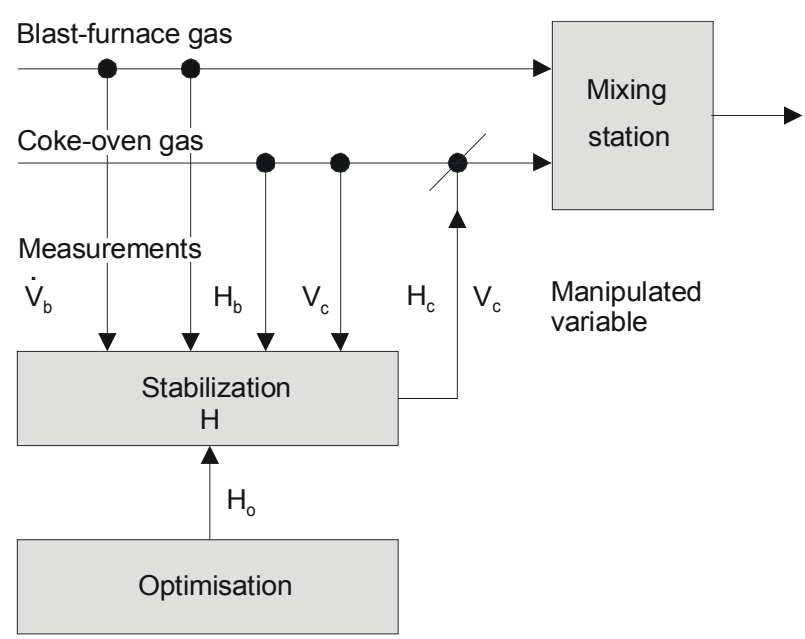

Figure 5. Forward system of stabilization calorific value Slika 5. Unaprijeđeni sistem stabilizacije ogrjevne vrijednosti

$$
b=y_{A} x_{A}+y_{B} x_{B}+y_{C} x_{C}
$$

The above optimization task (7) - (11) was solved with linear programming where the results are the optimal heat flows $Q_{b}^{0}, Q_{c}^{0}$.

For the instantaneous known heat capacities of the heating gases $H_{b}, H_{c}$ we can determine their volume flows and then the optimum heating capacity is given by relation (12)

$$
H^{0}=\frac{Q_{c}^{0}+Q_{b}^{0}}{\dot{V}_{c}+\dot{V}_{b}}
$$

In Figure 6. is shown the behavior of optimum heating capacity of mixture gas in dependence on the capacity of the coke battery. This dependence is the result of optimisation task (7) - (12) by linear programming. In real time, the optimisation level sents a values of optimum heating capacity to stabilization level. The stabilization level in a new forward control system then regulates the volume flow of coke-oven gas to mixing station (see Figure 5.).

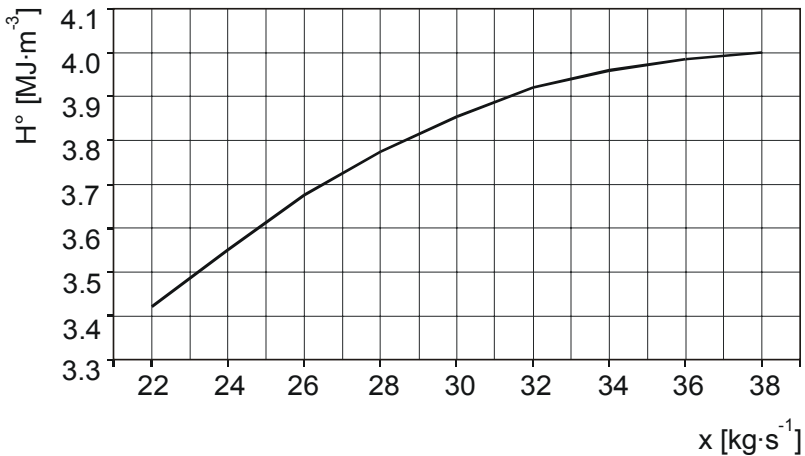

Figure 6. The optimum trajectory of heating capacity of mixture gas

Slika 6. Optimalna krivulja ogrjevnog kapaciteta smjese plinova
It is clear that from this solution optimum volume flow of the coke and blast furnace gas is known as well. During verification of this system for stabilization of the heat capacity of mixture gas, a possibility of choice of (cheap) blast furnace gas was left to the energy dispatcher, and for this reason only automated control of the volume flow of coke gas $\dot{V}_{c}$ was realized.

The manipulated variable is given by computating the volume flow of coke-oven gas according to the formula

$\dot{V}_{c}=\frac{\dot{V}_{b} H_{b}-\dot{V}_{c} H^{0}}{H^{0}-H_{c}}$

where

$\dot{V}_{c}$ is the volume flow of coke oven gas,

$\dot{V}_{b}$ is the volume flow of blast furnace gas,

$H_{b}$ is the calorific value of blast furnace gas,

$H_{c}$ is the calorific value of coke oven gas,

$H^{0}$ is the desired optimum calorific value of mixed gas.

\section{CONCLUSION}

The new system architecture of optimum control is gradually realized. This brings an increase of economy without bigger costs and investment into technology. For example, the realization only of the stabilization level brings about $3 \%$ energy savings.

A new design of optimum control of coke battery was suggested with the aim of reducing the energy cost of coke production. The first optimization level makes use of differences in heat efficiency of individual blocks of the coke battery. Currently it is in a verification stage. The second optimization level was already realized. Its role is to determine the optimum heating capacity of the mixture gas. Its realization also forced a change in the stabilization of the heat capacity which changes depending on the performance. The contribution of this system for stabilization of heating capacity is the following:

1. energy savings approximately at the level of 3\% [4];

2. higher quality of control of heating testified by smaller temperature deviations from the required values at the end of the process of coking;

3. easier control of the coke battery.

\section{REFERENCES}

1. K. Kostúr: Automatizace, (1987) 8-9, 199-203

2. K. Kostúr: Transaction of the Technical University of Košice, (1994) 4, 193-199

3. K. Kostúr: Metalurgija 36 (1997) 1, 33-36

4. K. Kostúr, R. Palo, P. Flegner: Model for computing of optimal calorific value of mixed gas. Research report, OAR Košice, 2000 